\title{
Effect of nitrogen and sulfur on yield and yield components of sesame (Sesamum indicum L.) in calcareous soil
}

\author{
Nangial Khan ${ }^{1 *}$, Shad Khan Khalil ${ }^{1}$, Amanullah ${ }^{1}$, Akhtar Ali $^{1}$, Zia \\ $\mathrm{Ullah}^{2}$ and Murad $\mathrm{Ali}^{3}$ \\ 1. Department of Agronomy, The University of Agriculture Peshawar, Pakistan \\ 2. Department of Water Management, The University of Agriculture Peshawar, Pakistan \\ 3. Department of Soil and Environmental Sciences, The University of Agriculture Peshawar, Pakistan \\ *Corresponding author's email: nangialkhan@ hotmail.com
}

Citation

Nangial Khan, Shad Khan Khalil, Amanullah, Akhtar Ali, Zia Ullah and Murad Ali. Effect of nitrogen and sulfur on yield and yield components of sesame (Sesamum Indicum L.) in calcareous soil.Pure and Applied Biology. Vol. 5, Issue 3, pp471-475. http://dx.doi.org/10.19045/bspab.2016.50061

\begin{tabular}{llll}
\hline \hline Received: $31 / 12 / 2015$ & Revised: 17/05/2016 & Accepted: 25/05/2016 & Online First: 28/05/2016 \\
\hline
\end{tabular}

Abstract

The study was carried out on sesame in North West of Pakistan. The experiment was laid out in RCBD having 3 replications. Four $\mathrm{N}$ and three $\mathrm{S}$ rates were applied in two splits one at sowing and second split with first irrigation. No of pods plant ${ }^{-1}$ and grain yield $\left(\mathrm{kg} \mathrm{ha}^{-1}\right)$ were affected significantly by N, S and control vs rest. No of grains $\operatorname{pod}^{-1}$ and 1000 -seeds weight were affected significantly affected by nitrogen not sulfur. Mean values for nitrogen exhibited that highest grain yield (799.4) were obtained at $70 \mathrm{~kg} \mathrm{~N} \mathrm{ha}^{-1}$, while minimum grain yield (637) were recorded at 0 $\mathrm{kg} \mathrm{N} \mathrm{ha}{ }^{-1}$. Mean values for sulfur revealed that highest grain yield (807.1) were recorded at $30 \mathrm{~kg}$ $\mathrm{S} \mathrm{ha}^{-1}$, while minimum grain yield (628.6) were recorded at $10 \mathrm{~kg} \mathrm{~S} \mathrm{ha}^{-1}$. Nitrogen and sulfur interaction showed that optimum grain yield $\left(1030 \mathrm{~kg} \mathrm{ha}^{-1}\right)$ was noted at $70: 30 \mathrm{~kg} \mathrm{~N}: \mathrm{S} \mathrm{ha}^{-1}$, while minimum grain yield $\left(516.10 \mathrm{~kg} \mathrm{ha}^{-1}\right)$ was noted at $150: 10 \mathrm{~kg} \mathrm{~N}^{-\mathrm{S} \mathrm{ha}^{-1}}$. It is concluded that nitrogen and sulfur applied at the rate of $70: 30 \mathrm{~kg} \mathrm{~N}: \mathrm{S} \mathrm{ha}^{-1}$ perform better as compared to other treatment applied and thus recommended for attaining high yield.

Key words: Nitrogen; Sulfur: Sesame: Yield

\section{Introduction}

Sesame (Sesamum indicum L.) belongs to Pedaliaceae family. Till is its local name in Urdu and Punjabi, in Sindhi it is called tir, Konzala in Pashto and in Balochi it is called Kunjit. It is an oilseed crop. It is annual minor kharif short-day plant, and it flowers normally in 42-45 days [1]. Its stem is erect and branched. The roots develop more profusely in sandy soil than in clay soil which imparts drought resistance to sesame. Flowers on short peduncles are borne singly in the axils of leaves of the upper portion of the stem and branches. The fruit of sesame is called capsule and it varies from 2.5 to 8.0 $\mathrm{cm}$ in length and 0.5 to $2.0 \mathrm{~cm}$ in diameter. Capsules starts maturing form bottom to top, allowing shattering of the lower ones by the time the uppermost capsules are mature. Seeds of sesame are small, ovate and are of two types due to its color differentiation, one is cream-colored and other type is black. Most people like Cream-colored seeds for use in sweet dishes and other foods. Sesame 
is grown in tropical zones as well as in temperate zones. In Asia and Africa it is cultivated from centuries. The world production of sesame seed was 3,976,968 tons in 2009 and the major production area was Asia (2,489,518 tons) and Africa (1,316,690 tons), constituting about $62.6 \%$ and $33.1 \%$ of the total world production [2]. The sesame seed contains all necessary fatty acids and amino acids. It is a best source of vitamins and minerals. The seed cakes of sesame are also used as nutritious feed for livestock [3]. Sesame is considered as a drought tolerant crop [4]. In Pakistan, sesame was cultivated on an area of 90.7 ha with an annual production of 41 tones and an average yield of $452 \mathrm{~kg} \mathrm{ha}^{-1}$ in Pakistan whereas in Khyber Pakhtunkhwa its average yield was $500 \mathrm{~kg} \mathrm{ha}^{-1}[5]$. Nitrogen is most important nutrient for enlargement of leaf and expansion of roots. Due to these reasons, nitrogen increased crop yield and quality [6]. Seed oil contents were increased by $\mathrm{N}$ application except at the highest rate $(90 \mathrm{~kg}$ $\mathrm{N} \mathrm{ha}^{-1}$ ) which slowly reduced oil content compared with the control(zero)[7]. Sulfur is also famous as one of the essential elements for plant growth particularly for oilseed crops. Sulfur is a constituent of three amino acids commonly found in plants such as cysteine and methionine, which are essential components of proteins. Sulfur gives pungency to oil as it forms di sulphide linkages and also increases oil content. Oilseed crops require more sulfur than cereals as their oil storage organs are mostly proteins, rich in S. Sulfur deficiency delay N metabolism in plants as well as synthesis of S-containing amino acids and thus exerts adverse effects on both seed and oil yield.

Soil and climatic conditions of Pakistan are highly encouraging for sesame production. Among the various factors of crop production proper sowing dates, nitrogen levels, sulfur levels and improved sesame cultivars play a key role in enhancing its production. Keeping in view the above limitations this research was conducted to check out the impact of nitrogen and sulfur levels on the yield and yield components of sesame at the agro-climatic condition of Northwestern Pakistan.

\section{Materials and methods Site description}

The field experiment was studied at The Agronomy Research Farm, The University of Agriculture Peshawar, during kharif 2013. The experiment was laid out in RCBD with three replications. A subplot size of $2.7 \mathrm{~m} \mathrm{x}$ $3 \mathrm{~m}$ was used. Each sub plot was consisted of 6 rows having $45 \mathrm{~cm}$ row-to-row distance. Local black variety of sesame was sown on June 29, 2013.During the entire crop season four irrigations were applied and two time manual weeding was done. Phosphorus was applied at the recommended rate of $60 \mathrm{~kg} \mathrm{ha}^{-}$ 1. Seed rate was kept $4 \mathrm{~kg} \mathrm{ha}^{-1}$ and all other agronomic practices were carried out consistently for all the experimental units throughout the growing season. The crop was harvested on October 24, 2013.

\section{Treatments of the experiment}

$\begin{array}{lc} & \mathrm{N}: \mathrm{S}\left(\mathrm{kg} \mathrm{ha}^{-1}\right) \\ \mathrm{T} 1= & 30: 10 \\ \mathrm{~T} 2= & 30: 20 \\ \mathrm{~T} 3= & 30: 30 \\ \mathrm{~T} 4= & 70: 10 \\ \mathrm{~T} 5= & 70: 20 \\ \mathrm{~T} 6= & 70: 30 \\ \mathrm{~T} 7= & 110: 10 \\ \mathrm{~T} 8= & 110: 20 \\ \mathrm{~T} 9= & 110: 30 \\ \mathrm{~T} 10= & 150: 10 \\ \mathrm{~T} 11= & 150: 20 \\ \mathrm{~T} 12= & 150: 30 \\ \mathrm{~T} 13= & 0: 0(\text { Control })\end{array}$

\section{Statistical Analysis:}

Data was subjected to analysis of variance (ANOVA) according to the methods described by Steel and Torrie (1980) and mean difference $\mathrm{b} / \mathrm{w}$ treatments was 
compared by least significance difference at $5 \%$ level of probability.

\section{Results and discussion}

\section{Number of pods plant ${ }^{-1}$}

Number of pods plant ${ }^{-1}$ were affected positively by different levels of nitrogen, sulfur, control vs. rest and their interaction ( $\mathrm{N} \times \mathrm{S})$. In (Table 1) mean values for nitrogen proved that more number of pods plant $^{-1}$ (174.9) were recorded at $110 \mathrm{~kg} \mathrm{~N} \mathrm{ha}^{-}$ 1 , while less number of pods plant ${ }^{-1}$ (138) were recorded at $0 \mathrm{~kg} \mathrm{~N} \mathrm{ha}^{-1}$. In case of sulfur (Table 3) more number of pods plant ${ }^{-}$ 1 (196.1) were recorded at $30 \mathrm{~kg} \mathrm{~S} \mathrm{ha}^{-1}$, While less number of pods plant ${ }^{-1}$ (138) were recorded at $0 \mathrm{~kg} \mathrm{~S} \mathrm{ha}^{-1}$. In case of Interaction $\mathrm{N} \times \mathrm{S}$ (Table 4) more number of seeds pod $^{-1}$
(220.7) were recorded at $70 \mathrm{~kg} \mathrm{~N}$ and $30 \mathrm{~kg}$ $\mathrm{S} \mathrm{ha}^{-1}$, while less number of seeds pod $^{-1}$ (109.3) were recorded at $70 \mathrm{~kg} \mathrm{~N}$ and $10 \mathrm{~kg}$ $\mathrm{S} \mathrm{ha}^{-1}$. The number of pods were significantly influenced by application of $\mathrm{N}$ fertilizer [8]. $\mathrm{N}$ fertilizer application at 75 and $112.5 \mathrm{~kg} \mathrm{~N} \mathrm{ha}^{-1}$ did not differ significantly from each other but differ with 37.5 and $0 \mathrm{~kg} \mathrm{~N} \mathrm{ha}^{-1}$ rates with higher values. The effect of different sulfur applications were statistically significant on number of capsules per plant [9]. Capsules per plant were increased by each increment of nitrogen fertilizer [10]. Application of sulfur at $40 \mathrm{~kg} \mathrm{ha}^{-1}$ produced higher pods plant ${ }^{1}[11]$

Table 1. Impact of nitrogen and sulfur on control vs. rest of sesame.

\begin{tabular}{|c|c|c|c|c|}
\hline $\begin{array}{l}\text { Cont } \\
\text { vs. Rest }\end{array}$ & No of pods plant ${ }^{-1}$ & No of seeds pod ${ }^{-1}$ & 1000 grains wt $(\mathrm{g})$ & Grain yield(kg ha-1) \\
\hline Control & $138 b$ & $63 b$ & $5 b$ & $637 b$ \\
\hline Rest & $170 \mathrm{a}$ & $73 b$ & $6 a$ & $714 a$ \\
\hline
\end{tabular}

\section{Number of seeds pod $^{-1}$}

Number of seeds pod $^{-1}$ were affected significantly by nitrogen and control vs. rest, while non-significantly affected by sulfur and the interaction of nitrogen and sulfur. In (Table 2) mean values for nitrogen mediated that more number of seeds pod ${ }^{-1}$ (73.9) were obtained at $150 \mathrm{~kg} \mathrm{~N} \mathrm{ha}^{-1}$, while less number of seeds pod ${ }^{-1}$ (63) were attained at $0 \mathrm{~kg} \mathrm{~N} \mathrm{ha}^{-}$ ${ }^{1}$. In case of sulfur (Table 3 ) more number of seeds $\operatorname{pod}^{-1}$ (72.3) were achieved at $20 \mathrm{~kg} \mathrm{~S}$ $\mathrm{ha}^{-1}$, while less number of seeds pod $^{-1}$ (63) were recorded at control. In case of interaction $(\mathrm{N} \times \mathrm{S})($ Table 4$)$ more number of seeds $\operatorname{pod}^{-1}$ (76.3) were recorded at $110 \mathrm{~kg} \mathrm{~N}$ and $30 \mathrm{~kg} \mathrm{~S} \mathrm{ha}^{-1}$, while less number of seeds $\operatorname{pod}^{-1}$ (68) were recorded at $30 \mathrm{~kg} \mathrm{~N}$ and 10 $\mathrm{kg} \mathrm{S} \mathrm{ha}^{-1}$. The higher significance difference among nitrogen levels for number of seeds capsule $^{-1}$ was recorded [3]. More number of seeds capsule ${ }^{-1}$ (62.83) were produced when nitrogen was applied at the rate of $80 \mathrm{~kg} \mathrm{ha}^{-1}$. Also more number of seeds per capsule were recorded by increasing sulfur levels [12].

Table 2. Impact of Nitrogen on yield and yield components of sesame.

\begin{tabular}{|c|c|c|c|c|}
\hline $\mathbf{N}\left(\mathbf{k g ~ h a}^{-\mathbf{1}}\right)$ & No of pods plant $^{-1}$ & No of seeds pod $^{\mathbf{1}}$ & $\mathbf{1 0 0 0}$ grains wt. (g) & Grain yield(kg ha $\left.^{\mathbf{1}}\right)$ \\
\hline $\mathbf{3 0}$ & $169.9 \mathrm{ab}$ & $70.7 \mathrm{~b}$ & $5.6 \mathrm{~b}$ & $668.1 \mathrm{c}$ \\
\hline $\mathbf{7 0}$ & $165.6 \mathrm{~b}$ & $72.9 \mathrm{a}$ & $6.9 \mathrm{a}$ & $799.4 \mathrm{a}$ \\
\hline $\mathbf{1 1 0}$ & $174.9 \mathrm{a}$ & $73.4 \mathrm{a}$ & $5.4 \mathrm{~b}$ & $733.9 \mathrm{~b}$ \\
\hline $\mathbf{1 5 0}$ & $169.1 \mathrm{~b}$ & $73.9 \mathrm{a}$ & $5.9 \mathrm{ab}$ & $653.3 \mathrm{c}$ \\
\hline $\mathbf{L S D}(\mathbf{0 . 0 5})$ & 5.32 & 2.08 & 1.02 & 49.30 \\
\hline
\end{tabular}

\section{0-seeds weight}

1000 -seeds weight of sesame was positively affected by nitrogen, while affected non- significantly by control vs. rest, sulfur and interaction between nitrogen and sulfur. In (Table 2) mean values for nitrogen showed 
that maximum 1000-seeds weight (6.9) were noted at $70 \mathrm{~kg} \mathrm{~N} \mathrm{ha}^{-1}$, while minimum 1000seeds weight (5) were produced at $0 \mathrm{~kg} \mathrm{~N} \mathrm{ha}^{-}$ ${ }^{1}$. In case of sulfur (Table 3 ) maximum 1000seeds weight (6.2) were produced at $30 \mathrm{~kg} \mathrm{~S}$ $\mathrm{ha}^{-1}$, while minimum 1000 -seeds weight (5) were obtained at $0 \mathrm{~kg} \mathrm{~S} \mathrm{ha}{ }^{-1}$. In case of interaction $(\mathrm{N} \times \mathrm{S})$ (Table 4) maximum 1000seeds weight (7.3) were recorded at $70 \mathrm{~kg} \mathrm{~N}$ and $20 \mathrm{~kg} \mathrm{~S} \mathrm{hac}{ }^{-1}$, while minimum 1000grain weight were recorded at $150 \mathrm{~kg} \mathrm{~N}$ and $10 \mathrm{~kg} \mathrm{~S} \mathrm{hac}{ }^{-1}$. 1000-seed weight was significantly affected by nitrogen levels [3]. The maximum 1000-seed weight (3.42 g) was obtained in $\mathrm{N}_{2}\left(80 \mathrm{~kg} \mathrm{ha}^{-1}\right)$ treatment, followed by $\mathrm{N}_{1}\left(40 \mathrm{~kg} \mathrm{ha}^{-1}\right)$ treatment that resulted in $3.22 \mathrm{~g}$ weight of 1000-kernals.

Table 3. Impact of Sulfur on yield and yield components of sesame

\begin{tabular}{|c|c|c|c|c|}
\hline$S\left(\mathrm{~kg} \mathrm{ha}^{-1}\right)$ & No of pods plant ${ }^{-1}$ & No of seeds pod ${ }^{-1}$ & 1000 grains wt. $(\mathrm{g})$ & Grain yield $\left(\mathrm{kg} \mathrm{ha}^{-1}\right)$ \\
\hline 10 & $139.0 \mathrm{c}$ & $71.9 \mathrm{~b}$ & $5.6 \mathrm{a}$ & $628.6 c$ \\
\hline 20 & $174.5 b$ & $72.3 \mathrm{ab}$ & $6.1 \mathrm{a}$ & $705.4 \mathrm{~b}$ \\
\hline 30 & $196.1 \mathrm{a}$ & $74.0 \mathrm{a}$ & $6.2 \mathrm{a}$ & $807.1 \mathrm{a}$ \\
\hline $\operatorname{LSD}(0.05)$ & 4.60 & $\mathrm{Ns}$ & $\mathrm{Ns}$ & 42.69 \\
\hline
\end{tabular}

Table 4. Impact of Nitrogen and Sulfur interaction on yield and yield components of sesame

\begin{tabular}{|c|c|c|c|c|c|}
\hline N Level & S Level & No of pods plant ${ }^{-1}$ & No of seeds pod ${ }^{-1}$ & 1000 grains wt. (g) & $\begin{array}{c}\text { Grain yield } \\
\left(\mathrm{kg} \mathrm{ha}^{-1}\right)\end{array}$ \\
\hline \multirow[t]{3}{*}{30} & 10 & 154.3 & 68.0 & 5.3 & 696.0 \\
\hline & 20 & 167.0 & 71.3 & 5.3 & 583.3 \\
\hline & 30 & 188.3 & 72.7 & 6.0 & 725.0 \\
\hline \multirow[t]{3}{*}{70} & 10 & 109.3 & 73.0 & 6.3 & 585.0 \\
\hline & 20 & 166.7 & 73.0 & 7.3 & 783.3 \\
\hline & 30 & 220.7 & 72.7 & 7.0 & 1030.0 \\
\hline \multirow[t]{3}{*}{110} & $\mathbf{1 0}$ & 137.7 & 71.3 & 5.7 & 716.7 \\
\hline & 20 & 200.7 & 72.7 & 5.0 & 711.7 \\
\hline & 30 & 186.3 & 76.3 & 5.7 & 773.3 \\
\hline \multirow[t]{3}{*}{150} & 10 & 154.7 & 75.3 & 5.0 & 516.7 \\
\hline & 20 & 163.7 & 72.0 & 6.7 & 743.3 \\
\hline & 30 & 189.0 & 74.3 & 6.0 & 700.0 \\
\hline $\operatorname{LSD}(0.05)$ & & $* *$ & Ns & $\mathrm{Ns}$ & $* *$ \\
\hline
\end{tabular}

\section{Grain yield $\left(\mathrm{Kg} \mathrm{ha}^{-1}\right)$}

Grain yield of sesame was significantly affected by nitrogen, sulfur, control vs rest and interaction between nitrogen and sulfur. In (Table 2) mean values for nitrogen indicated that maximum grain yield (799.4) were produced at $70 \mathrm{~kg} \mathrm{~N} \mathrm{ha}{ }^{-1}$, while minimum grain yield (637) were obtained at $0 \mathrm{~kg} \mathrm{~N} \mathrm{ha}{ }^{-1}$. In case of sulfur (Table 3) maximum grain yield (807.1) were recorded at $30 \mathrm{~kg} \mathrm{~S} \mathrm{ha}^{-1}$, while minimum grain yield (628.6) were recorded at $10 \mathrm{~kg} \mathrm{~S} \mathrm{ha}^{-1}$. In case of interaction $(\mathrm{N} \times \mathrm{S})$ (Table 4) maximum grain yield (1030) were produced at $70 \mathrm{~kg} \mathrm{~N}$ and $30 \mathrm{~kg} \mathrm{~S} \mathrm{hac}{ }^{-1}$, while minimum grain yield (516.7) were recorded at $150 \mathrm{~kg} \mathrm{~N}$ and $10 \mathrm{~kg}$ $\mathrm{S} \mathrm{ha}^{-1}$. The application of $60 \mathrm{~kg} \mathrm{~N} \mathrm{ha}{ }^{-1}$ produced significantly higher grain yield as compared with other levels of $\mathrm{N}$ application [13]. Yield was reduced by increasing $\mathrm{N}$ rate from 60 to $120 \mathrm{~kg} \mathrm{~N} \mathrm{ha}^{-1}$. The application of $\mathrm{S}$ increased TDM and seed yield in oil seed crops [11]. The application of S increased the grain yield of sesame and the capsule number plant $^{-1}$ [9]. Also seed yield was increased by $39 \%$ as compared to control [14]. 


\section{Conclusion}

From the results we concluded that nitrogen application at $70 \mathrm{~kg} \mathrm{ha}^{-1}$ gave maximum 1000 -seeds weight and grain yield and sulfur application at $30 \mathrm{~kg} \mathrm{ha}^{-1}$ gave maximum no of pods plant ${ }^{-1}$, number of grains pod ${ }^{-1}, 1000$ seeds weight and grain yield. $70 \mathrm{~kg} \mathrm{~N} \mathrm{ha}^{-1}$ and $30 \mathrm{~kg} \mathrm{~S} \mathrm{ha}^{-1}$ were proper nutrients combinations for improved growth yield characters of sesame viz. increases 1000seeds weight and grain yield.

\section{Authors' contributions}

Designed the experiments: N Khan \& SK Khalil, Performed the experiments: N Khan, A Ali \& Z Ullah, Analyzed the data: N Khan A Ullah \& SK Khalil, Contributed reagents/materials/analysis tools: M Ali \& A Ali, Wrote the paper: N Khan.

\section{References}

1. Nazir S (1994). Crop production NBF,Islmabad.

2. FAOSTAT (2011). FAO Statistics Division 2011; Sesame seed. In: Food and Agriculture Organization of United Nation.

3. Malik MA, Saleem MF, Cheema MA \& Ahmad S (2003). Influencce of different nitrogen levels on productivity of sesame (Sesamumindicum L.) under varying planting patterns. Int j Agri Biol 5(4):490-492.

4. Alpaslan M, Boydak E, Hayat M, Grereck S \& Simsek M (2001). Effect of row spacing and irrigation on seed composition of Turkish sesame. J. of the American oil chemist's Society 78(9):933-935.

5. MINFAL (2009). Ministry for Food, Agriculture and Livestock. Govt. of Pakistan, economic wing,Islamabad.

6. Khalil IA \& Jan A (2002). Cropping technology. National book Foundation, Islamabad.

7. Ramakrishna A, Ssundaramand A \& Appavoo V (1994). Influence of fertilization on yield and yield components of sesame (Sesamum indicum L.). Madras Agric J 81: 696-698.
8. Shehu EH, Kwari JW \& Sandabe V (2010). Effect of Nitrogen, phosphorus and potassium nutrition of sesame (Sesamum indicumL.). Intl Journal of agri Bio 12:845-850.

9. Heidari M, Galavi M \& Hassani.M (2011). Effect of sulfur and iron fertilizers on yield, yield components and nutrient uptake in sesame (Sesamum indicum L.) under water stress. Department of Agronomy Plant Breeding, University of Zabol, Zabol, Iran. African Journal of Biotechnology 10(44):8816-8822.

10. Shilpi S, Islam MN, Sutradhar GNC, Husna A \& Akter F (2012). Effect of nitrogen and sulfur on the growth and yield of sesame. International Journal of Bio-resource and Stress Management 3(2):177-182.

11. Shelke RI, Kalegore NK \& Wayase KP (2014). Effect of levels of phosphorus and sulphur on growth,yield and quality of sesame (Sesamum indicum L.). World Journal of Agricultural Sciences 10(3):108-111.

12. Tiwari DD, Pandey SB \& Katiyar NK. 2015. Effects of Polyhalite as a fertilizer on yield and quality of the oilseed crops mustard and sesame. Azad University of agriculture and technology, department of soil science and agricultural chemistry, Kanpur, India. 42: $10-34$.

13. Haruna IM (2011). Growth and yield of sesame (Sesamum indicum L.) as affected by poultry manure, nitrogen and phosphorus at Samaru, Nigeria. J Anim Plant Sci 21(4): 805820.

14. Mondal M, Baddrudin M, Malek M, Hossain M \& Puteh A (2012). Optimization of sulfur requirement to sesame (Sesamum indicumL.) genotypes using tracer techniques. Bangladesh Journal of Botany 41(1):7-13.

15. Tahir M, Ibrahim MA, Tahir S, Ayub A, Tanveer A \& Rehman H (2014). Effect of Sulfur Levels on Two Sesame (Sesamum indicum L.) Varieties under Climatic Conditions of Pakistan. Int. $j$ of Plant Soil Science 3(3): 281-288. 